\title{
Uwarunkowania prawne realizowania zadań gmin w zakresie pobierania i egzekwowania opłaty za gospodarowanie odpadami komunalnymi po nowelizacji ustawy z dnia 28 listopada 2014 r. o zmianie ustawy o utrzymaniu czystości i porządku w gminach Wybrane zagadnienia praktyczne
}

Jarostaw Kotowski

Członek Kolegium Regionalnej izby Obrachunkowej w Zielonej Górze

http://dx.doi.org/10.18778/8088-114-3.25

Do dnia 1 lutego 2015 r. czyli do dnia wejścia w życie nowelizacji ustawy z dnia 28 listopada 2014 r. o zmianie ustawy o utrzymaniu czystości i porządku w gminach oraz o zmianie niektórych innych ustaw (Dz.U. z 2015, poz. 87) w zakresie różnicowania stawek opłaty za gospodarowanie odpadami komunalnymi obowiązywała dyspozycja art. 6k ust. 4 ustawy, zgodnie z którym rada gminy określając warunki opłat zgodnie z metodą, o której mowa w art. 6 j ust. 1 i 2, mogła różnicować stawki opłat, wprowadzać zwolnienia przedmiotowe, ustanawiać dopłaty dla właścicieli nieruchomości, o których mowa $\mathrm{w}$ art. $6 \mathrm{c}$ ust. 1, spełniających ustalone przez nią kryteria lub określić szczegółowo zasady ustalania tych opłat. Zatem rada gminy uprawniona była zarówno do różnicowania stawek opłat bez względu na przyjętą metodę wyliczenia opłaty od nieruchomości zamieszkałych, o której stanowił art. 6j ust. 1 ustawy, jak również mogła różnicować opłatę w sytuacji przyjęcia jednolitej metody ponoszenia opłaty od gospodarstwa domowego. Ponadto rada upoważniona była do wprowadzania zwolnień przedmiotowych (nie podmiotowych) oraz mogła wprowadzać dopłaty dla właścicieli nieruchomości.

Po nowelizacji ustawy z dniem 1 lutego 2015 roku sytuacja przedstawia się inaczej. Na pierwszym miejscu wskazać należy, że z dniem 1 lutego tego 
roku utracił moc obowiązującą art. 6k ust. 4 ustawy w dotychczasowym brzmieniu. Nie oznacza to jednak, że upoważnienie do różnicowania stawek opłaty zostało z ustawy wykluczone. Zgodnie bowiem z dyspozycją art. 6j ust. 2a ustawy w brzmieniu obowiązującym od 1 lutego 2015 r. rada może różnicować może zróżnicować stawki opłaty w zależności od powierzchni lokalu mieszkalnego, liczby mieszkańców zamieszkujących nieruchomość, odbierania odpadów z terenów wiejskich lub miejskich, a także od rodzaju zabudowy. Zatem kryteriami różnicującymi stawki opłaty są nadal powierzchnia lokalu mieszkalnego, w przypadku metody od powierzchni, w zależności od liczby mieszkańców, w przypadku metody od mieszkańca, odbioru odpadów z terenów miejskich lub wiejskich (w zależności od częstotliwości odbioru i tras odbioru odpadów), oraz od rodzaju zabudowy - zabudowa zwarta, rozproszona jednorodzinna, wielorodzinna mieszana z przewagą funkcji mieszkalnych. Zatem nadal kwestia różnicowania wysokości stawek opłaty może występować - natomiast nowelizacja wykluczyła w całości zwolnienia przedmiotowe oraz stosowanie dopłat dla właścicieli nieruchomości. Oznacza to w istocie, że nawet jeśli gmina czy związek międzygminny posiada w obrocie prawnym regulacje dotyczące dopłat dla właścicieli nieruchomości lub regulacje dotyczące zwolnień przedmiotowych, to w sytuacji, gdy akt prawa miejscowego regulujący to zagadnienie pozostaje w obrocie prawnym po 1 lutego 2015 r., to w tym zakresie nie może być stosowany, bowiem odpadła podstawa prawna dla jego stosowania.

W zakresie zarówno dopłat dla właścicieli nieruchomości jak i zwolnień przedmiotowych - uchwały w tym zakresie (w tej części) powinny zostać uchylone z obrotu prawnego.

Kwestia różnicowania stawek opłaty jest w moim przekonaniu jednym z kluczowych elementów elastyczności systemu gospodarowania odpadami komunalnymi, jednakże należy również zauważyć, że ustawodawca wprowadzając do ustawy art. 6r ust. 1aa ucpg, zgodnie z którym środki pochodzące $z$ opłaty za gospodarowanie odpadami komunalnymi nie mogą być wykorzystane na cele niezwiązane $z$ pokrywaniem kosztów funkcjonowania systemu gospodarowania odpadami komunalnymi, nie tylko uczynił z opłaty za gospodarowanie pieniądz znaczony w budżecie, ale również ustawodawcy przyświecał cel dążenia do zbilansowania systemu gospodarowania odpadami komunalnymi. Oczywiście wspomniane wyżej różnicowanie stawek opłaty może znacząco utrudnić bilansowanie się systemu z uwagi na konieczność odbioru wszystkich odpadów komunalnych z nieruchomości objętych systemem, o czym stanowi wprost art. 6r ust. 2d ustawy z możliwością ograniczenia jedynie ilości odpadów zielonych, zużytych opon, odpadów wielkogabarytowych oraz odpadów budowlanych i rozbiórkowych stanowiących odpady komunalne odbieranych lub przyjmowanych przez punkty selektywnego zbierania odpadów 
komunalnych (vide art. 6r ust. 3a ustawy). Ponadto różnicowanie stawki oznacza, że przy podobnych ilościach odpadów zielonych, zmieszanych, oraz odbieranych $\mathrm{z}$ nieruchomości zamieszkałych i niezamieszkałych w sposób selektywny ponoszona jest przez właścicieli nieruchomości opłata w różnej wysokości. Zauważyć należy że sama definicja bilansowania systemu gospodarowania odpadami komunalnymi nie została w ustawie wprost sformułowana. Co więcej sam ustawodawca w art. $6 \mathrm{r}$ ust. 2c, poprzez wprowadzenie zapisu „środki pochodzące z opłat za gospodarowanie odpadami komunalnymi, które nie zostały wykorzystane w poprzednim roku budżetowym, mogą być wykorzystane także na wyposażenie, zgodnie z regulaminem, nieruchomości przeznaczonych do celów publicznych w pojemniki przeznaczone do zbierania odpadów komunalnych, ich opróżnianie oraz utrzymywanie w odpowiednim stanie sanitarnym, porządkowych i technicznym", dostrzegł problem konieczności przesądzenia o przeznaczeniu nadwyżki opłaty pozostałej do wykorzystania po zakończeniu roku budżetowego. Otwarte pozostaje pytanie, czy wobec zapisu art. 6r ust. 2c ustawy o utrzymaniu czystości i porządku $\mathrm{w}$ gminach pozostała po zakończeniu roku w ramach pobranej opłaty za gospodarowanie odpadami komunalnymi nadwyżka może być wykorzystana tylko na cel wskazany $\mathrm{w}$ art. $6 \mathrm{r}$ ust. $2 \mathrm{c}$ ustawy czy też może być wykorzystana na zadania $\mathrm{z}$ zakresu utrzymania czystości i porządku w gminach, czy jak twierdzą niektórzy wchodzi w wolne środki, a więc po zakończeniu roku powiększa nadwyżkę budżetową - albo zmniejsza deficyt budżetu, a ostatecznie o jej przeznaczeniu decyduje wyłącznie organ stanowiący gminy.

Pomimo braku ustawowej definicji bilansowania systemu gospodarowania odpadami komunalnymi wskazać trzeba, że orzecznictwo sądów administracyjnych jeszcze przed nowelizacją ustawy dokonaną w 2014 roku zdefiniowało zasadę bilansowania się systemu gospodarowania odpadami komunalnymi. W świetle orzeczenia WSA w Białymstoku $\mathrm{z}$ dnia 24 stycznia 2014 r. sygn. I Sa/Bk 525/13 (www.orzeczenia.nsa.gov.pl). „Prawidłowo skalkulowana opłata za gospodarowanie odpadami komunalnymi powinna $\mathrm{z}$ jednej strony zapewniać sprawne funkcjonowanie systemu odbioru odpadów na terenie gminy, $\mathrm{z}$ drugiej zaś nie powinna stanowić źródła dodatkowych zysków gminy”. „Rzetelna kalkulacja wysokości opłat powinna w szczególności uwzględniać liczbę mieszkańców gminy, ilość wytwarzanych na terenie gminy odpadów komunalnych oraz koszty funkcjonowania systemu gospodarowania odpadami, na który składają się koszty odbierania, transportu, zbierania, odzysku i unieszkodliwiania odpadów komunalnych, tworzenia i utrzymania punktów selektywnego zbierania odpadów komunalnych oraz obsługi administracyjnej tego systemu". W ocenie WSA to organ stanowiący powinien wziąć pod uwagę wszystkie w/w elementy i tak skalkulować stawkę, aby 
system został zbilansowany, a więc środków wystarczało na funkcjonowanie systemu, a z drugiej strony, aby opłata nie stanowiła dodatkowego dochodu dla gmin $\mathrm{z}$ uwagi na stawkę zawyżoną względem rzeczywistych kosztów funkcjonowania systemu. Jednakże zauważyć należy, że kolejną przeszkodą w osiągnieciu celu w postaci zbilansowania systemu będzie realizacja (często ze względów społecznych) dodanego z dniem 1 lutego 2015 r. art. 6k ust. 4 ustawy o utrzymaniu czystości i porządku w gminach, zgodnie, z którym rada gminy, w drodze uchwały, może zwolnić w całości lub w części z opłaty za gospodarowanie odpadami komunalnymi właścicieli nieruchomości, na których zamieszkują mieszkańcy, w części dotyczącej gospodarstw domowych, w których dochód nie przekracza kwoty uprawniającej do świadczeń pieniężnych z pomocy społecznej, o której mowa w art. 8 ust. 1 lub 2 ustawy $\mathrm{z}$ dnia 12 marca 2004 r. o pomocy społecznej (Dz.U. z 2013 r., poz. 182, ze zm.). Otóż na wstępie omawiania zagadnienia nowej regulacji dotyczącej zwolnień wskazać należy, że mogą one dotyczyć wyłącznie nieruchomości, na których zamieszkują mieszkańcy ale tylko w części tych nieruchomości, która dotyczy gospodarstw domowych, co ma szczególne znaczenie przy nieruchomościach wielolokalowych o różnym przeznaczeniu faktycznym (częściowo mieszkalnym, częściowo handlowym czy usługowym). Nie oznacza to jednak w moim przekonaniu, że jedynie wybór jednolitej stawki od gospodarstwa domowego upoważnia do zastosowania tego zwolnienia. Należy to raczej wiązać $\mathrm{z}$ brakiem możliwości zwalniania $\mathrm{w}$ tym trybie nieruchomości przeznaczonych na cele wypoczynkowo-rekreacyjne i innych podobnego rodzaju, czy też wykorzystywanych na prowadzenie działalności gospodarczej. Warunkiem wprowadzenia i zastosowania tego zwolnienia jest jednak to, aby dochód w gospodarstwie domowym (niezależnie od przyjętej metody obliczenia opłaty), nie przekraczał kwoty uprawniającej do świadczeń z pomocy społecznej w rozumieniu art. 8 ust. 1 ustawy o pomocy społecznej. Na uwagę zasługuje również odwołanie w art. $6 \mathrm{k}$ ust. 4 do art. 8 ust. 2 ustawy o pomocy społecznej, zgodnie z którym rada uprawniona jest do zwiększenia kryteriów dochodowych uprawniających do świadczeń ponad kryteria ustawowe, co oznacza de facto możliwość szerszego zastosowania zwolnień z ponoszenia opłaty za gospodarowanie odpadami komunalnymi w całości lub w części.

Zauważyć jednak trzeba, że zawarte w art. 6k ust. 4 ustawy o utrzymaniu czystości i porządku w gminach odwołanie do art. 8 ust. 1 i 2 ustawy o pomocy społecznej jest niewystarczające z punktu widzenia braku możliwości przeprowadzania $\mathrm{w}$ tym zakresie chociażby wywiadu środowiskowego. Niemniej jednak wobec braku możliwości skorzystania w tym zakresie z rozwiązań określonych ustawą o pomocy społecznej, rozwiązań pomocnych dla organów administracji publicznej w zakresie prawidłowości weryfikacji dokonanych zwolnień szukać należy na grun- 
cie ustawy o utrzymaniu czystości i porządku w gminach oraz na gruncie ordynacji podatkowej. Na wstępie zauważyć należy, że uprawnienie dla rady w zakresie określonym $\mathrm{w}$ art. $6 \mathrm{k}$ ust. 4 ma charakter fakultatywny, a jego realizacja może prowadzić do całkowitego lub częściowego zwolnienia z ponoszenia opłaty. Ponadto art. $6 \mathrm{k}$ ust. 4 znowelizowanej ustawy nie uprawnia rady gminy, ani do wprowadzenia zasad dokonywania zwolnień ani trybu jego realizacji. Zatem należy rozwiązania tego zagadnienia $\mathrm{w}$ praktyce poszukiwać na gruncie znowelizowanego $\mathrm{z}$ dniem 1 lutego 2015 r. art. $6 \mathrm{~m}$ ust. $1 \mathrm{~b}$ pkt 3, który w zakresie danych, jakich organ administracji publicznej może żądać od podatnika opłaty za gospodarowanie odpadami komunalnymi wskazuje na możliwość żądania w ramach dokumentów załączonych do deklaracji „śmieciowej” danych stanowiących podstawę zwolnienia $\mathrm{z}$ opłaty za gospodarowanie odpadami komunalnymi. Dane wskazywane w deklaracji dotyczyć powinny jedynie liczby osób w gospodarstwie domowym oraz oświadczenia o wysokości dochodu branego do obliczenia jako podstawa uprawniająca do świadczeń z pomocy społecznej na podstawie art. 8 ust. 1 ustawy o pomocy społecznej lub jeśli rada zwiększyła kryterium dochodowe na podstawie art. 8 ust. 2 tej ustawy.

Oświadczenie wraz z danymi złożonymi w tym zakresie w deklaracji, nie powinno być składane pod rygorem odpowiedzialności karnej, ani też pod rygorem innego rodzaju odpowiedzialności, bowiem ustawodawca $\mathrm{w}$ art. $6 \mathrm{k}$ ust. 4 ani w art. $6 \mathrm{~m}$ ustawy o utrzymaniu czystości i porządku takiego rygoru nie przewidział, ani nie upoważnił organu stanowiącego do jego wprowadzenia w drodze uchwały wydanej na podstawie art. $6 \mathrm{n}$ ustawy o utrzymaniu czystości i porządku w gminach. Weryfikacja złożonego oświadczenia, tak jak i całej deklaracji, następowała będzie albo poprzez żądanie na podstawie art. 6 n ust. 2 ustawy o utrzymaniu czystości i porządku w gminach dodatkowych dokumentów potwierdzających dane $\mathrm{w}$ zakresie uprawnienia do korzystania ze zwolnienia, albo poprzez zastosowanie dyspozycji art. 60 ustawy, zgodnie z którym w razie niezłożenia deklaracji o wysokości opłaty za gospodarowanie odpadami komunalnymi albo uzasadnionych wątpliwości co do danych zawartych w deklaracji wójt, burmistrz lub prezydent miasta określa, w drodze decyzji, wysokość opłaty za gospodarowanie odpadami komunalnymi, biorąc pod uwagę dostępne dane właściwe dla wybranej przez radę gminy metody, a w przypadku ich braku - uzasadnione szacunki, w tym w przypadku nieruchomości, na których nie zamieszkują mieszkańcy, średnią ilość odpadów komunalnych powstających na nieruchomościach o podobnym charakterze. Opłata za gospodarowanie odpadami komunalnymi w wysokości określonej w decyzji, obowiązuje do końca miesiąca poprzedzającego miesiąc, w którym następuje zmiana danych niezbędnych do określenia wysokości tej opłaty. Po doręczeniu decyzji zgodnie z art. 6o ust. 
3 ustawy, złożenie deklaracji nie jest dopuszczalne, jeżeli nie następuje zmiana danych niezbędnych do określenia wysokości tej opłaty, w tym stawki opłaty. Jednakże właściciel nieruchomości, wobec którego została wydana decyzja określająca wysokość opłaty, w przypadku zmiany danych jest obowiązany do złożenia deklaracji, dotyczy to również przypadku zmiany stawki opłaty za gospodarowanie odpadami komunalnymi, która to zmiana jest przecież od właściciela niezależna. Inne jeszcze zagadnienie dotyczy lub rodziny wielodzietne, o których mowa w ustawie z dnia 5 grudnia 2014 r. o Karcie Dużej Rodziny (Dz.U. poz. 1863 oraz z 2015 r., poz. 1359). Niezależnie zatem od uprawnień jakie posiada rada gminy wobec osób korzystających ze świadczeń pomocy społecznej które mogą być objęte zwolnieniem z opłaty śmieciowej w całości (lub w części - ulga) ustawodawca wprowadza kolejne zwolnienie podmiotu jakim jest tzw. Duża rodzina w myśl ustawy o karcie dużej rodziny, a więc w założeniu rodzina licząca dwoje dorosłych osób oraz co najmniej troje dzieci w wieku do 18 lat lub do ukończenia nauki - nie dłużej jednak niż do ukończenia 25 lat. Zwolnienie to podobnie jak w przypadku osób korzystających ze świadczeń pomocy społecznej ma charakter fakultatywny, a wątpliwości prawne może jedynie budzić zwolnienie częściowe mająca charakter ulgi procentowej w ponoszeniu opłaty - bowiem podmiotem zwalnianym częściowo nie będzie tutaj np. 4 . i kolejne dziecko ale cała rodzina wielodzietna, co będzie tym trudniejsze w gminach, gdzie opłaty za gospodarowanie odpadami są ponoszone według metody od mieszkańca nie zaś od gospodarstwa domowego.

Stosownie natomiast do art. 6q ust. 1 ustawy o utrzymaniu czystości i porządku w gminach w brzmieniu ustalonym nowelizacją, która w zasadniczej części regulacji obowiązuje od 1 lutego 2015 r. w sprawach dotyczących opłat za gospodarowanie odpadami komunalnymi stosuje się przepisy ustawy z dnia 29 sierpnia 1997 r. - Ordynacja podatkowa, z tym że uprawnienia organów podatkowych przysługują wójtowi, burmistrzowi lub prezydentowi miasta, a w przypadku przejęcia przez związek międzygminny zadań gminy, o których mowa w art. 3 ust. 2, w zakresie gospodarowania odpadami komunalnymi, $\mathrm{w}$ zakresie opłat za gospodarowanie odpadami komunalnymi, które stanowią dochód związku międzygminnego - zarządowi związku międzygminnego. Przechodząc zatem na grunt ordynacji podatkowej zastosowanie do weryfikacji danych $\mathrm{w}$ zakresie legalności korzystania ze zwolnień określonych $\mathrm{w}$ art. $6 \mathrm{k}$ ust. 4 ustawy, wskazać należy na uprawnienie organu do prowadzenia czynności sprawdzających na podstawie art. 272 ustawy Ordynacja podatkowa. Skutkiem ich prowadzenia może być wydanie decyzji z art. 60 ustawy lub chociażby, w wyniku negatywnej weryfikacji prawa do korzystania ze zwolnienia $\mathrm{z}$ całości lub części opłaty $\mathrm{z}$ art. $6 \mathrm{k}$ ust. 4 , może po- 
wodować wszczęcie kontroli podatkowej lub postępowania podatkowego na zasadach przewidzianych w ordynacji podatkowej. Powstaje jednak istotne pytanie, na ile możliwość wprowadzenia zwolnienia częściowego z ponoszenia opłaty nie będzie traktowana jako forma ukrytej ulgi w jej ponoszeniu i czy w tym zakresie wobec zaliczenia opłaty za gospodarowanie do kategorii opłat lokalnych i utrwalonego w orzecznictwie sądów poglądu o dopuszczalności zwolnień przedmiotowych w opłatach lokalnych tego wprowadzone rozwiązanie w postaci częściowego zwolnienia z ponoszenia opłaty powinno być $\mathrm{w}$ ogóle akceptowalne?

Oczywiście nie sposób przy tym nie wskazać, że tego typu zwolnienia $\mathrm{z}$ ponoszenia opłaty o charakterze całkowitym lub częściowym, przy możliwych problemach z ustaleniem ilości osób faktycznie do nich uprawnionych i weryfikacją tych danych, mogą podobnie jak różnicowanie stawek zaburzyć istotnie zasadę bilansowania się systemu gospodarowania odpadami komunalnymi.

Kolejny aspekt wart podniesienia w niniejszych rozważaniach dotyczy wprowadzonej ustawą z dnia 28 listopada 2014 r. o zmianie ustawy o utrzymaniu czystości i porządku w gminach oraz o zmianie niektórych innych ustaw (Dz.U. z 2015, poz. 87) nowej regulacji do art. 6q ust. 3 ustawy o utrzymaniu czystości i porządku w gminach, zgodnie z którą w przypadku złożenia korekty deklaracji lub nowej deklaracji zmniejszającej wysokość zobowiązania z tytułu opłaty za gospodarowanie odpadami komunalnymi nie stwierdza się nadpłaty w tej opłacie za miesiące, w których usługa odbierania odpadów komunalnych była świadczona.

Złożenie korekty deklaracji jest co do zasady dopuszczalne wobec dyspozycji art. 6q ust. 1 ustawy o utrzymaniu czystości i porządku w gminach zgodnie $\mathrm{z}$ którym do spraw dotyczących opłaty za gospodarowanie odpadami komunalnymi stosuje się przepisy ustawy Ordynacja podatkowa z tym, że uprawnienia organów podatkowych przysługują wójtowi, burmistrzowi lub prezydentowi miasta, a w przypadku przejęcia przez związek międzygminny zadań gminy, o których mowa w art. 3 ust. 2, $\mathrm{w}$ zakresie gospodarowania odpadami komunalnymi, w zakresie opłat za gospodarowanie odpadami komunalnymi, które stanowią dochód związku międzygminnego - zarządowi związku międzygminnego.

Korekta deklaracji, stosownie do art. 81 ustawy Ordynacja podatkowa jest możliwa do dokonania przez podatnika w każdym czasie i ustawodawca nie wprowadza w tym zakresie ograniczenia czasowego. Wydaje się w świetle działu III Ordynacji, że do czasu przedawnienia zobowiązania taka korekta byłaby możliwa. Jedyne istotne ograniczenie w zakresie dokonywania korekty formułuje dyspozycja art. 81b ustawy Ordynacja podatkowa, zgodnie $\mathrm{z}$ którym uprawnienie to ulega zawieszeniu i tym samym nie może zostać przez podatnika opłaty za gospodarowanie odpadami komunalnymi zrealizowane $\mathrm{w}$ okresie trwania postępowania 
podatkowego lub kontroli podatkowej - w zakresie objętym tym postępowaniem lub kontrolą.

Uprawnienie to zostaje jednak przywrócone dla podatnika niezwłocznie po zakończeniu kontroli podatkowej lub postępowania podatkowego, w zakresie nieobjętym decyzją określającą wysokość zobowiązania podatkowego wynikającą z art. 6o ustawy o utrzymaniu czystości i porządku w gminach.

Jednakże, co ważne, należy pamiętać, że korekta deklaracji z tytułu opłaty za gospodarowanie odpadami komunalnymi dokonana w okresie trwania postępowania podatkowego lub kontroli podatkowej nie wywołuje ani dla podatnika ani dla organu podatkowego skutków prawnych.

Samo faktyczne dokonanie korekty, zgodnie z art. $81 \$ 2$ ustawy Ordynacja podatkowa, następuje przez złożenie korygującej deklaracji wraz $\mathrm{z}$ dołączonym pisemnym uzasadnieniem przyczyn korekty. Korekta jest zatem inną sytuacją od zmiany danych od których zależy wysokość opłaty za gospodarowanie odpadami komunalnymi tj. np. ilości mieszkańców zamieszkujących nieruchomość lub ilości odpadów odbieranych z nieruchomości, która powoduje konieczność stosownie do art. $6 \mathrm{~m}$ ust. 2 ustawy o utrzymaniu czystości i porządku w gminach po nowelizacji złożenia nowej deklaracji, nie zaś obowiązek składania jej korekty. Wobec powyższego korekta deklaracji może być jak się wydaje składana do czasu przedawnienia zobowiązania $\mathrm{z}$ tytułu obowiązku ponoszenia opłaty za gospodarowanie odpadami komunalnymi.

W świetle dyspozycji znowelizowanego art. 6q ustawy o utrzymaniu czystości i porządku w gminach, oba warianty tj. złożenie deklaracji (nowej) w warunkach wynikających $\mathrm{z}$ art. $6 \mathrm{~m}$ ust. 2 ustawy o utrzymaniu czystości i porządku w gminach jak i jej korekty w rozumieniu art. 81 ustawy Ordynacja podatkowa, których skutkiem jest tylko i wyłącznie zmniejszenie wysokości zobowiązania z tytułu opłaty za gospodarowanie odpadami komunalnymi powoduje, że z mocy prawa (art. 6q ust. 3 ustawy) nie stwierdza się nadpłaty w tej opłacie za miesiące, w których usługa odbierania odpadów komunalnych była świadczona.

Kwestia stwierdzania nadpłaty w opłacie za gospodarowanie odpadami komunalnymi nie jest regulowana przepisami ustawy o utrzymaniu czystości i porządku w gminach.

Przechodząc na grunt regulacji ustawy ordynacja podatkowa, stosowanej wprost do spraw dotyczących opłaty za gospodarowanie odpadami komunalnymi na podstawie art. 6q ustawy o utrzymaniu czystości i porządku w gminach, stwierdzić należy, że stosownie do art. $73 \$ 1$ Ordynacji podatkowej nadpłata powstaje, $\mathrm{z}$ zastrzeżeniem $\$ 2$, z dniem:

1) zapłaty przez podatnika podatku nienależnego lub w wysokości większej od należnej; 
2) pobrania przez płatnika podatku nienależnego lub w wysokości większej od należnej;

3) zapłaty przez płatnika lub inkasenta należności wynikającej z decyzji o jego odpowiedzialności podatkowej, jeżeli należność ta została określona nienależnie lub w wysokości większej od należnej;

4) wpłacenia przez płatnika lub inkasenta podatku w wysokości większej od wysokości pobranego podatku;

5) zapłaty przez osobę trzecią lub spadkobiercę należności wynikającej z decyzji o odpowiedzialności podatkowej lub decyzji ustalającej wysokość zobowiązania podatkowego spadkodawcy, jeżeli należność ta została określona nienależnie lub w wysokości większej od należnej;

Natomiast o ile nadpłata powstaje w sytuacjach innych niż wymienione w art. $73 \$ 1$ Ordynacji podatkowej, to stosownie do art. 74a Ordynacji, wysokość nadpłaty określa organ podatkowy.

Zgodnie z art. $75 \$ 1$ Ordynacji podatkowej, jeżeli podatnik kwestionuje zasadność pobrania przez płatnika podatku albo wysokość pobranego podatku, może złożyć wniosek o stwierdzenie nadpłaty podatku. W przypadku opłaty za gospodarowanie odpadami komunalnymi lex specialis do dyspozycji tego przepisu pozostaje art. 6q ust. 3, który wskazuje, że może wystąpić sytuacja, w której organ podatkowy gminy lub zarząd związku międzygminnego nie stwierdzi jednak nadpłaty na wniosek podatnika za ten miesiąc lub miesiące, w których usługa odbierania odpadów komunalnych była świadczona.

Problemy praktyczne występują jednak z praktycznym odkodowaniem znaczenia jakie ustawodawca nadał sformułowaniu „w których usługa odbierania odpadów komunalnych była świadczona”. Definicji tego pojęcia nie zawiera ani znowelizowana ustawa o utrzymaniu czystości i porządku w gminach, ani też ustawa o odpadach. Poprzez takie uregulowanie stwierdzić należy, że ocena dokonana przez organ podatkowy - korekty deklaracji lub nowej deklaracji dotyczyła będzie tego okresu, w którym nastąpiła zmiana skutkująca tylko i wyłącznie zmniejszeniem wysokości opłaty.

Natomiast ocena, czy usługa odbierania odpadów komunalnych była świadczona może być odczytywana co najmniej na dwóch płaszczyznach. Po pierwsze jako faktyczny odbiór odpadów z nieruchomości przez podmiot odbierający odpady za okres, którego dotyczy korekta lub nowa deklaracja, ale również jako gotowość odbioru, a więc sytuacja w której przedsiębiorca odbierający odpady wysłał śmieciarkę do tej nieruchomości lecz faktycznego odbioru śmieci z tej konkretnej nieruchomości nie było. Zauważyć należy, że ani ustawa o utrzymaniu czystości i porządku w gminach, ani ustawa o odpadach nie definiują pojęcia świadczenia usługi odbierania odpadów komunalnych. Jednym racjonalnym, jak się wydaje, rozwiązaniem byłoby do czasu nowelizacji ustawy o utrzymaniu 
czystości lub ustawy o odpadach definiowanie tego pojęcia w SIWZ oraz umowach na odbiór lub odbiór i zagospodarowanie odpadów świadczonych na podstawie art. 6d ustawy zapisywać definicję tego pojęcia oraz rozważenie możliwości wprowadzenia tego pojęcia do regulaminów utrzymania czystości i porządku w gminach i objaśnień do deklaracji, o których sanowi art. $5 \mathrm{~m}$ i $6 \mathrm{n}$ ustawy o utrzymaniu czystości i porządku w gminach. Zagadnienie to będzie bowiem bardzo istotne w sytuacji np. śmierci podatnika i pojawienia się w urzędzie jego spadkobiercy, który na nieruchomości nie zamieszkiwał i zażąda stwierdzenia nadpłaty w rozumieniu Ordynacji podatkowej, w sytuacji gdy organ podatkowy stwierdzi że gotowość do świadczenia usługi po stronie przedsiębiorcy była lub nawet usługa była świadczona (ktoś wrzucał odpady do pojemnika zmarłej osoby i usługa była realnie wykonywana). Sytuacja ta budzi wiele kontrowersji również wobec dyspozycji art. 76 Ordynacji podatkowej, wobec którego może powstać pytanie, na poczet jakiego zobowiązania nadpłatę zaliczyć w sytuacji, gdy mimo świadczenia usługi np. zmarły podatnik wpłacił całą opłatę za rok z góry, a zmarł po 2 miesiącach od tej wpłaty, zaś spadkobierca na nieruchomości otrzymanej w drodze spadkobrania nie mieszka i nie wytwarza odpadów i zamierza ją sprzedać, zatem nie jest podatnikiem opłaty za gospodarowanie odpadami komunalnymi. Stosownie bowiem do art. $76 \$ 1$ i 2 Ordynacji podatkowej nadpłaty wraz $\mathrm{z}$ ich oprocentowaniem podlegają zaliczeniu z urzędu na poczet zaległości podatkowych wraz z odsetkami za zwłokę, odsetek za zwłokę określonych w decyzji, o której mowa w art. 53a, oraz bieżących zobowiązań podatkowych, a w razie ich braku podlegają zwrotowi z urzędu, chyba że podatnik złoży wniosek o zaliczenie nadpłaty w całości lub w części na poczet przyszłych zobowiązań podatkowych, z zastrzeżeniem $\$ 2$. Zgodnie natomiast $\mathrm{z}$ dyspozycją art. $76 \$ 2$ wskazanej wyżej ustawy, nadpłaty, których wysokość nie przekracza wysokości kosztów upomnienia $\mathrm{w}$ postępowaniu egzekucyjnym, podlegają $\mathrm{z}$ urzędu zaliczeniu na poczet zaległości podatkowych wraz z odsetkami za zwłokę, odsetek za zwłokę określonych w decyzji, o której mowa w art. 53a, oraz bieżących zobowiązań podatkowych, a w razie ich braku - na poczet przyszłych zobowiązań podatkowych, chyba że podatnik wystąpi o ich zwrot. Zatem o ile nie będzie sytuacji, w której nadpłata będzie mogła być zaliczona na poczet zobowiązań bieżących lub przyszłych, będzie ona musiała podlegać zwrotowi. Jedynym wyjątkiem może być sytuacja $\mathrm{z}$ art. $6 \mathrm{q}$ ust. 3 ustawy o utrzymaniu czystości i porządku w gminach o ile orzecznictwo sądów administracyjnych lub sam ustawodawca dopracuje się definicji pojęcia „usługa odbioru odpadów była świadczona” tak, aby rozwiać wątpliwości, co do tego, w jakich sytuacjach nadpłata w ogóle nie powstanie, a w jakich znajdą zastosowanie reguły wyrażone w art. 76 Ordynacji podatkowej. 
Przedstawiony aspekt nadpłat i konieczności ich zwrotów również może zniweczyć starania j.s.t., w zakresie zbilansowania systemu gospodarowania odpadami komunalnymi.

Kolejny aspekt dotyczy problemu związanego z zawieraniem porozumień z naczelnikami urzędów skarbowych - dotyczących przekazania przez nich na rzecz organów gmin i związków uprawnień organów egzekucyjnych. Po wprowadzeniu art. 6qa do ustawy o utrzymaniu czystości i porządku w gminach z dniem 18 kwietnia 2015 roku. W sytuacji zawierania takich porozumień zastosowanie znajduje dyspozycja art. 8 ust. 2 do ust. 5 ustawy o samorządzie gminnym, co oznacza, że gmina z mocy prawa otrzymuje środki finansowe $\mathrm{w}$ wysokości koniecznej do wykonania zadań, o których mowa w art. 8 ust. 1, 2 i 2a ustawy o samorządzie gminnym. Zatem o ile porozumienie zostanie zawarte, to budżet państwa powinien zapewnić środki finansowe na wykonywanie zadania zleconego w postaci prowadzenia zadań egzekucyjnych. Brak środków finansowych $\mathrm{w}$ budżecie państwa oraz obawy praktyczne przed zawieraniem porozumień mogą zniweczyć w wielu wypadkach skuteczność egzekucji opłaty śmieciowej, lub ją zmarginalizować (wobec ograniczonej ilości personelu w wydziałach egzekucyjnych urzędów skarbowych i ilości nałożonych zadań), a to wprost może spowodować brak możliwości zbilansowania systemu przy rosnących kosztach i nowych zadaniach nałożonych do realizacji z opłaty śmieciowej - przy równoczesnym braku woli wielu organów stanowiących urealnienia stawek opłat za gospodarowanie odpadami komunalnymi. 